\title{
Probiotic viability, viscosity, hardness properties and sensorial quality of synbiotic ice creams produced from goat's milk
}

\author{
Merve ACU ${ }^{1}$ (D), Ozer KINIK ${ }^{2}$ (D), Oktay YERLIKAYA ${ }^{2 *}$
}

\begin{abstract}
This research aimed to examine the probiotic viability of bacteria, rheological and sensorial properties in synbiotic ice creams produced from goat's milk combined with probiotic culture and prebiotics. Tagatose, Litesse ultra and polydextrose (as prebiotics) were used in ice cream production and mixtures and these mixtures were inoculated with Bifidobacterium bifidum, Lactobacillus paracasei and Bifidobacterium longum combined culture. Frozen raspberry fruits, commercial raspberry and blackberry fruit purees were used as taste flavor enhancers in synbiotic ice cream. Four different ice cream types were produced including control sample. Probiotic bacteria viability, apparent viscosity, hardness and sensory properties were examined during the 120-day- storage. It was determined that frozen fruit and fruit purees addition and using prebiotics significantly affected the Lactobacillus paracasei and Bifidobacterium spp. viability and color, appearance, flavor, taste and overall sensory scores of the synbiotic goat's milk ice creams $(P<0.05)$. Synbiotic ice cream samples maintained their probiotic properties during storage and were generally well appreciated in terms of sensory properties.
\end{abstract}

Keywords: goat's milk; ice cream; prebiotics; probiotic viability; synbiotics.

Practical Application: In this study, ice cream production with functional properties has been developed by using goat's milk. Within the scope of the study, probiotic cultures that were used less in probiotic products were tried and ice creams were enriched with fruit and fruit purees. As a result of the research, probiotic viability remained at the desired level and a dairy product with the possibility of commercialization was produced.

\section{Introduction}

Probiotics is defined as "[...] live microorganisms that, when administered in adequate amounts, confer a health benefit on the host [...]" (Hill et al., 2014). Today, numerous dairy products with probiotic additives are produced at the industrial level (Markowiak \& Śliżewska, 2017). Lactobacillus acidophilus, Lactobacillus paracasei and Bifidobacterium species isolated from human and animal intestinal tract are the most common bacteria used as probiotics. The use of probiotic preparations including these bacteria in industrial food production systems have become increasingly widespread in accordance with consumer demands (Kechagia et al., 2013).

Dairy products are the most probiotic food carrier (Champagne et al., 2018) with several benefits to consumer health (Sarfraz et al., 2019; Shafi et al., 2019; Vasconcelos et al., 2019) and technological parameters (Guimarães et al., 2020). Non bovine dairy foods present relevance as probiotic carrier (Ranadheera et al., 2018) and in particular ice cream is a probiotic dairy food with several examples (Ayar et al., 2018; Balthazar et al., 2018; Kalicka et al., 2019).

Prebiotics are nutrients that can directly pass to the large intestine without being digested in the small intestine and increase the activity of probiotics, thus, increasing the beneficial effects of probiotics in the bowel system (O'Bryan et al., 2013). Products created by the combined use of probiotics and prebiotics are called synbiotics. With synbiotic application, the life span of probiotic bacteria is prolonged and these bacteria can better colonize in the colon. In vitro studies show that synbiotic administration is more advantageous than the sole uses of prebiotics or probiotics (Pandey et al., 2015; Krumbeck et al., 2016).

Today, interest in probiotics, prebiotics and functional foods is constantly increasing. These subjects have become increasingly more popular in the academic studies and scientific studies on the benefits of probiotics to human health are added to the literature every day (Markowiak \& Śliżewska, 2017). Although yogurt and fermented dairy products are the main carriers of probiotic bacteria, products such as milk-based desserts, baby formulas, ice cream, butter, cheese types, capsules and powders dissolving in cold beverages and plant-origin fermented foods have become available in the international market in recent years (Heller, 2001; Shiby \& Mishra, 2013).

Ice cream, which is used as a probiotic carrier, is a dairy product obtained by processing milk and dairy products, sweeteners, stabilizers, emulsifiers, color and aroma substances by churning to have air spaces in the mixture (Marshall \& Arbuckle, 1996). There are many studies on synbiotic ice creams and their properties, where probiotics and prebiotics are used separately or in combination. Ice cream could present interesting properties, such as better melting features and desirable texture, if prepared 
with goat milk. When use of goat's milk in ice cream production, the color of ice cream becomes whiter. It also becomes rich in terms of total amount of dry matter (Homayouni et al., 2008, 2012; Ranadheera et al., 2019). Goat milk is also important for human health since it has high digestibility, low allergen effect properties, and contains functional compounds and proteins. In addition, the ice cream produced using goat milk has been shown to have better quality criteria and sensory properties (Paz et al., 2014; Zenebe et al., 2014; Lad et al., 2017). The aim of this research was to determine the viability of probiotic cultures, viscosity, hardness properties and sensorial quality of synbiotic goat's ice cream having improved functional properties.

\section{Materials and methods}

\subsection{Materials}

The raw goat's milk and skimmed milk powder were obtained from local dairy plants located in Bornova-Izmir while powdered sahlep (produced from the wild orchid plant) were provided from a local food market. Tagatose, Litesse ${ }^{\circledR}$ Ultra $^{\mathrm{Tm}}$ and polydextrose were provided from commercial manufacturers. Frozen raspberry fruit (Superfresh, Turkey), raspberry and blackberry purees (Aromsa, Turkey) were melted at room temperature and made ready for use. Probiotic lactic cultures (Lactobacillus paracasei subsp. paracasei Lafti L-26, Bifidobacterium longum + Bifidobacterium bifidum Lafti B-94) were obtained from DSM Food Specialties USA, Inc.

\subsection{Methods}

\section{Functional ice cream production}

Two replicate productions were carried out in the study with two duplicates. Sample codes and ice cream production stages of synbiotic ice cream samples are given in Figure 1.
The mixture consisted of skimmilk powder, tagatose (5\%), Litesse ultra $(0.67 \%)$, polydextrose $(1 \%)$ and sahlep. These ingredients were added to the raw milk and a subsequent pasteurization procedure was carried out at $90-95^{\circ} \mathrm{C}$ for $5-10$ minutes. Then the mixtures were cooled to $37-40^{\circ} \mathrm{C}$ and probiotic starter culture was inoculated in accordance with the commercial company's recommendations $\left(10^{8}-10^{9} \mathrm{Log} \mathrm{cfu} / \mathrm{g}\right)$. The inoculated mixtures were left to incubate at $37^{\circ} \mathrm{C}$. The incubation was carried out until the $\mathrm{pH}$ values reached 4.8-4.9 and ice cream samples stored at $+4{ }^{\circ} \mathrm{C}$ for 24 hours for ageing. The mixtures were divided into four groups and three of the groups were fortified with $10 \%$ frozen fruit or fruit purees. No fruit puree was added to the control group. Freezing procedure was carried out in a batch type ice cream machine and then the samples were packaged. The samples were analyzed for probiotic viability, viscosity, hardness values and sensory properties on the $1^{\text {st }}, 15^{\text {th }}, 30^{\text {th }}, 60^{\text {th }}, 90^{\text {th }}$, and $120^{\text {th }}$ days of the storage. All of the samples were produced in the pilot dairy plant located in Ege University, Izmir. For the production of raspberry puree, the raspberries were thawed, and then grounded and stirred on the stove.

\section{Probiotic bacteria counts in synbiotic goat's ice creams}

MRS-Vancomycin media for L. paracasei subsp. paracasei; MRS-NNLP (nalidixic acid, neomycin sulfate, lithium chloride, paromomycin sulfate) media for Bifidobacterium spp. was used. Petri plates were incubated at $37^{\circ} \mathrm{C}$ for $72 \mathrm{~h}$ using Anaerocult ${ }^{\circledR}$ A (Merck, Darmstadt, Germany) in anaoerobic jars (Merck, Darmstadt, Germany). 0.03 g nalidixic acid; 0.2 g neomycin sulfate, $6 \mathrm{~g}$ lithium chloride and $0.2 \mathrm{~g}$ paromomycin sulfate were added to the $1000 \mathrm{~mL}$ MRS Agar media by using $0.22 \mu \mathrm{m}$ diameter microfilter. $0.05 \%$ L-cysteine was added to medium. At the end of the incubation, dark white, high centered colonies with diameter of 1-1.5 mm were evaluated (Dave \& Shah 1996; Tharmaraj \& Shah, 2003; Donkor et al., 2006).

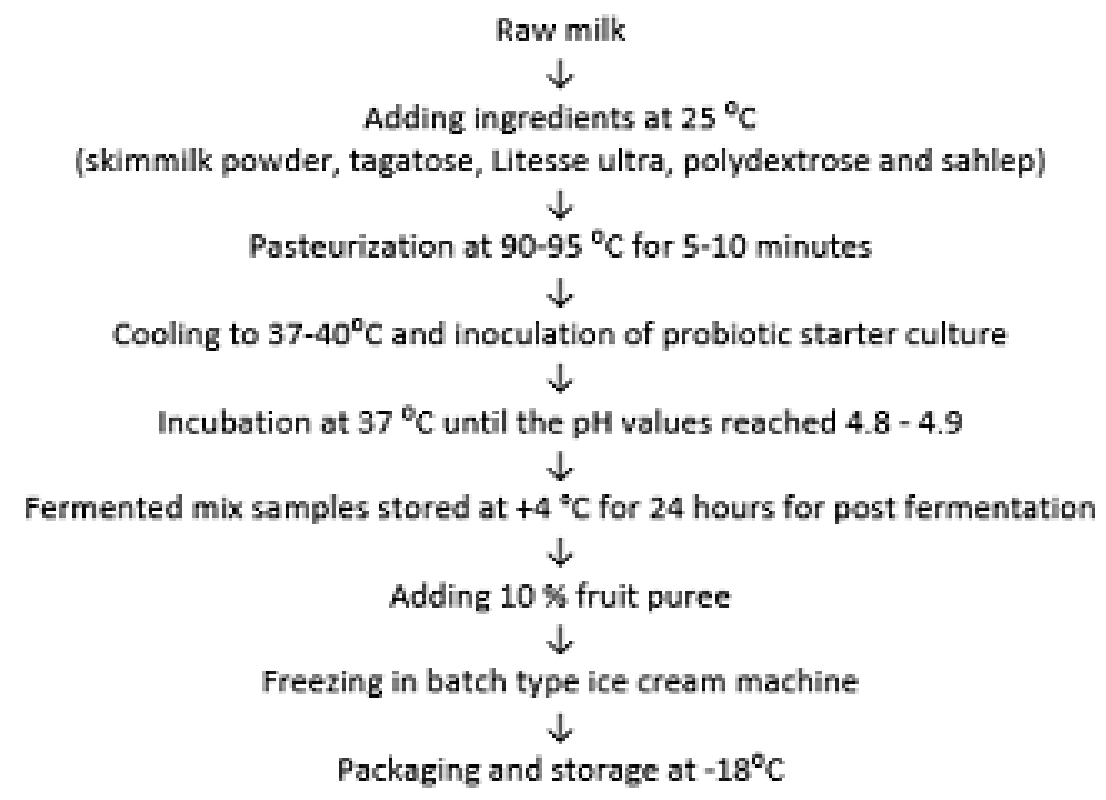

Figure 1. Flow diagram of synbiotic ice cream with fruit puree. 
Viscosity and textural analyses in synbiotic goat's ice creams

Viscosity analysis were performed by using Brookfield viscometer DV-II model at $60 \mathrm{rpm}$ for mixtures, and at $120 \mathrm{rpm}$ for ice cream samples at $8-10^{\circ} \mathrm{C}$ using $63=\mathrm{LV} 3$ spindle. The measurements were saved and the results were obtained using Rheocalc ${ }^{\circledR}$ application (Brookfield Engineering Laboratories Inc., ABD) software.

Textural properties (hardness) of synbiotic goat's ice cream samples were determined with Brookfield CT- 3 model texture analyzer. Texture readings were conducted between $-6^{\circ} \mathrm{C}$ to $-2{ }^{\circ} \mathrm{C}$ and texture application software (Brookfield Engineering Laboratories Inc., ABD) was utilized in the calculation of the results. TA 15/1000 conical probe was used for the analysis. Test speed was $2 \mathrm{~mm} / \mathrm{s}$, distance was $15 \mathrm{~mm}$, trigger load was $6.8 \mathrm{~g}$, the length was $40 \mathrm{~mm}$ and the diameter were $60 \mathrm{~mm}$.

\section{Sensory analysis}

Scoring test (Uysal et al., 2004) was utilized for the sensory evaluation of plain and fruit puree flavored synbiotic ice cream samples. The evaluation of sensory properties was conducted according to the sensory evaluation principles set forth in TS 4265 and each sample was evaluated accordingly. Sensory analyses of the synbiotic ice cream samples were carried out by trained and semi-trained panelists from Ege University, Faculty of Agriculture, Department of Dairy Technology. Accordingly, for scoring, evaluation card by Bodyfelt et al. (1988) was used with modifications. Ice cream samples were evaluated with the highest 5 points [very good (5), good (4) less defective (3) defective (2)] in terms of color-appearance, structure-consistency, odor and taste criteria. Sensory analyses were conducted on $1^{\text {st }}, 15^{\text {th }}, 30^{\text {th }}, 60^{\text {th }}, 90^{\text {th }}$ and $120^{\text {th }}$ days of the storage for each sample.

\section{Statistical analyses}

SPSS software package v15.00 (SPSS Inc. Chicago, Illinois) was used for the statistical analyses in the study. The significant differences were analyzed according to the Duncan multiple comparison test $(P<0.05)$. This analysis was made to assess the effects of prebiotics and different types of fruit purees on probiotic viability, rheology and sensorial properties of the samples.

\section{Results and discussion}

\subsection{Probiotic viability in synbiotic goat's ice creams}

It is undeniable that the viability of probiotic cultures during the shelf life decreased in the low storage temperature conditions and high acidity increases. Fluctuations in storage temperatures in ice cream technology can cause crystallization and therefore viability may decrease by cell fractionation (Ranadheera et al., 2012). In Table 1, 2, provides the viable count of probiotic cultures in symbiotic ice cream samples during the storage. It was found that B sample on day 1 of the storage period had the highest L. paracasei subsp. paracasei count (9.32 log cfu/g) and A sample day 1 of the storage period had the lowest count (7.70 log cfu/g). Furthermore, it was shown that B sample on day 1 of the storage period had the highest Bifidobacterium spp. count (9.15 log cfu/g), and A sample on day 1 of the storage period had the lowest count (7.69 log cfu/g).

It was detected that fruit purees and prebiotics had significant effect on L. paracasei subsp. paracasei and Bifidobacterium spp. counts $(P<0.05)$. While Bifidobacterium spp. count did not change significantly $(P>0.05)$; it was seen that L. paracasei subsp. paracase $i$ count changed only $1^{\text {st }}$ day of storage significantly. Tokuc et al. (2008) stated that Lactobacillus spp. remained stable as 7 log during 6 months storage period in probiotic ice cream production. Ranadheera et al. (2012) indicated that levels of Lactobacillus acidophilus La-5 and B. animalis subsp. lactis BB- 12 were protected $56.14 \%$ and $66.46 \%$, respectively in probiotic ice cream samples produced with goat milk. In compatible with the researchers' findings during 120 days of storage period probiotic bacteria count of synbiotic ice cream samples did not fall below 7.0; therefore, it could be said that ice cream samples maintained its probiotic characteristics. Probiotic foods are

Table 1. L. paracasei subsp. paracasei counts of synbiotic ice creams produced from goat's milk (log cfu/g).

\begin{tabular}{ccccccc}
\hline Samples & $1^{\text {st }}$ day & $15^{\text {th }}$ day & $30^{\text {th }}$ day & $60^{\text {th }}$ day & $90^{\text {th }}$ day & $120^{\text {th }}$ day \\
\hline C & $8.13 \pm 0.16^{\mathrm{x}}$ & $8.12 \pm 0.05$ & $8.02 \pm 0.18$ & $8.63 \pm 0.01$ & $8.44 \pm 0.08$ & $8.19 \pm 0.09$ \\
F & $8.37 \pm 0.39^{\mathrm{x}}$ & $8.02 \pm 0.10$ & $7.88 \pm 0.19$ & $8.47 \pm 0.10$ & $8.31 \pm 0.07$ & $8.03 \pm 0.14$ \\
A & $7.70 \pm 0.12^{\mathrm{x}}$ & $8.16 \pm 0.14$ & $8.06 \pm 0.38$ & $8.38 \pm 0.01$ & $8.23 \pm 0.14$ & $7.99 \pm 0.16$ \\
B & $9.32 \pm 0.02^{\mathrm{Cy}}$ & $8.34 \pm 0.13^{\mathrm{AB}}$ & $8.06 \pm 0.20^{\mathrm{A}}$ & $8.49 \pm 0.02^{\mathrm{B}}$ & $8.43 \pm 0.02^{\mathrm{AB}}$ & $8.17 \pm 0.14^{\mathrm{AB}}$ \\
\hline
\end{tabular}

${ }_{x, y}$ : Values with the different letters in the same column differ significantly $(P<0.05)$; ${ }^{\mathrm{A}, \mathrm{B}, \mathrm{C}}$ : Values with the different letters in the same row differ significantly $(P<0.05)$; C: Sample produced from freezing the fermented mixture no adding fruit puree, F: Sample produced from addition of frozen raspberries to the fermented mixture, A: Sample produced from addition of commercial raspberry puree to the fermented mixture, B: Sample produced from addition of commercial blackberry puree to the fermented mixture.

Table 2. Bifidobacterium spp. counts of synbiotic ice creams produced from goat's milk (log cfu/g).

\begin{tabular}{cccccc}
\hline Samples & $1^{\text {st }}$ day & $15^{\text {th }}$ day & $30^{\text {th }}$ day & $60^{\text {th }}$ day & $120^{\text {th }}$ day \\
\hline C & $8.03 \pm 0.41$ & $8.13 \pm 0.02$ & $7.91 \pm 0.23$ & $8.55 \pm 0.05$ & $8.41 \pm 0.14$ \\
F & $8.53 \pm 0.31$ & $8.04 \pm 0.10$ & $7.91 \pm 0.15$ & $8.34 \pm 0.23$ \\
A & $7.69 \pm 0.22$ & $7.93 \pm 0.16$ & $7.75 \pm 0.60$ & $8.27 \pm 0.00$ & $8.07 \pm 0.04$ \\
B & $9.15 \pm 0.07^{\mathrm{B}}$ & $8.19 \pm 0.17^{\mathrm{A}}$ & $8.12 \pm 0.11^{\mathrm{A}}$ & $8.41 \pm 0.03^{\mathrm{A}}$ & $8.40 \pm 0.15$ \\
\hline
\end{tabular}

$\mathrm{A}, \mathrm{B}$ : Values with the different letters in the same row differ significantly $(P<0.05)$; C: Sample produced from freezing the fermented mixture no adding fruit puree, F: Sample produced from addition of frozen raspberries to the fermented mixture, A: Sample produced from addition of commercial raspberry puree to the fermented mixture, B: Sample produced from addition of commercial blackberry puree to the fermented mixture. 
required to carry a specific live microorganism at a level of at least $10^{6}-10^{7} \mathrm{cfu} / \mathrm{g}$ during the storage period.

\subsection{Viscosity and hardness properties in synbiotic goat's ice creams}

Viscosity and hardness values of synbiotic goat's ice cream samples are presented in Table 3. As is seen in the results, viscosity values varied between $613.75-979.25 \mathrm{cP}$. The highest viscosity during storage period was determined in F sample at the $30^{\text {th }}$ day $(979.25 \mathrm{cP})$, and the lowest values was found in $\mathrm{C}$ sample at the $1^{\text {st }}$ day $(613.75 \mathrm{cP})$. The most challenging measurements were performed in raspberry puree ice creams. B sample could not be measured at $120 \mathrm{rpm}$ at the $60^{\text {th }}$ day. This may be due to the different viscosity of prebiotic supplement and different fruit purees. Generally speaking, viscosity values increased at the beginning of the storage and showed a decline at the further days. In general, it is normal for control sample to have lower values. Many ingredients adding the food composition can increase the viscosity values of the products. It could be said that addition of fruit purees and prebiotics increased the viscosity. Although fat content and viscosity are directly proportional, this relation was not as proportional in ice cream samples as is in the mixtures. However, this can be associated with the seed particles in the ice cream samples.

In all ice cream samples changes caused by storage and ingredients were significant $(P<0.05)$ whereas prebiotics and fruit puree use did not cause a significant difference between the samples only at the $30^{\text {th }}$ day of the storage $(P>0.05)$. Guven \& Karaca (2002), in their study on fruit ice cream containing sugar and strawberry at different ratios and vanilla yogurt ice creams, reported that viscosity increased parallel to the increase in sugar and fruit content. Muse \& Hartel (2004), in their study on ice cream production by using different emulsifiers and sweeteners, found the viscosity values between $621-935 \mathrm{cP}$. Akin (2005), reported the viscosity of probiotic yogurt ice cream samples between 842-1312 cP. Kesenkas et al. (2013) found the lowest viscosity during storage in ice cream samples produced from cow's milk while the highest viscosity was found in ice cream samples produced from the mixture prepared with the addition of kefir at $50 \%$ to the mixture produced with soy milk. Carbohydrate based ice cream mixtures containing fat substitutes which exhibiting a viscous behavior due to their water absorption capacity increase the viscosity of the system (Cottrell et al., 1979; Schmidt et al., 1993).

In the study, hardness values varied between 521.75$2127.25 \mathrm{~g}$. The highest texture value during storage period was determined in C sample at the $90^{\text {th }}$ day, while the lowest value was found in B sample at the $30^{\text {th }}$ day. In a general evaluation texture values, there were irregular fluctuations. Texture readings were performed with multi parallels and calculations were done based on the closest values.

Changes only in $\mathrm{C}$ samples in all ice cream groups were significant $(P<0.05)$, while the effect of prebiotics and fruit purees were statistically significant only at the $90^{\text {th }}$ day of the storage $(P<0.05)$. El-Nagar et al. (2002), in their study on the effect of inulin in yogurt ice creams, reported that inulin addition increased the hardness values of ice cream samples. Some researchers have also reported that low fat ice cream samples decreased the gumminess values during storage. Akalin et al. (2008) in their study on fat reduced and low fat ice creams, reported that fat ratio had a significant effect on the hardness values of ice cream samples $(P<0.05)$. Kesenkas et al. (2013) have reported that the texture values of the ice creams varied between 1237.7 and 4270.5. Lower results obtained in our study can be associated with the soft structure of ice cream samples.

\subsection{Sensory properties in synbiotic goat's ice creams}

Compared to classic ice cream products, flavor profiles of probiotic ice cream can substantially vary. Inulin and oligofructose improve the sensory properties including smoother feeling in the mouth, prolonged flavor with lower aftertaste and mild

Table 3. Viscosity and hardness values of synbiotic ice creams produced from goat's milk.

\begin{tabular}{|c|c|c|c|c|c|}
\hline & \multicolumn{5}{|c|}{ Synbiotic Ice Cream Samples } \\
\hline & Days & $\mathrm{C}$ & $\mathrm{F}$ & A & B \\
\hline \multirow[t]{6}{*}{ Viscosity (cP) } & 1 & $613.75 \pm 24.25^{\operatorname{Ax}}$ & $857.50 \pm 55.00^{\mathrm{By}}$ & $777.75 \pm 35.75^{\text {By }}$ & $725.50 \pm 20.50^{\operatorname{Axy}}$ \\
\hline & 15 & $690.75 \pm 36.25^{\mathrm{Bx}}$ & $969.75 \pm 12.75^{\mathrm{Cy}}$ & $687.75 \pm 30.25^{\operatorname{Ax}}$ & $971.00 \pm 13.00^{\text {By }}$ \\
\hline & 30 & $907.25 \pm 7.25^{\mathrm{D}}$ & $979.25 \pm 1.75^{\mathrm{C}}$ & $973.50 \pm 8.00^{C}$ & $924.25 \pm 50.25^{\mathrm{B}}$ \\
\hline & 60 & $812.25 \pm 14.25^{\mathrm{Cx}}$ & $844.00 \pm 8.50^{\mathrm{Bx}}$ & $784.00 \pm 2.50^{\mathrm{Bx}}$ & ${ }^{\star} \mathrm{ND}$ \\
\hline & 90 & $626.50 \pm 6.50^{\mathrm{ABx}}$ & $663.25 \pm 26.25^{\mathrm{Ax}}$ & $775.50 \pm 14.50^{\mathrm{By}}$ & $779.25 \pm 22.25^{\mathrm{Ay}}$ \\
\hline & 120 & $654.25 \pm 8.25^{\mathrm{ABx}}$ & $635.25 \pm 30.75^{\operatorname{Ax}}$ & $768.25 \pm 22.25^{\mathrm{By}}$ & $928.25 \pm 18.25^{\mathrm{Bz}}$ \\
\hline \multirow[t]{6}{*}{ Hardness (g) } & 1 & $1510.00 \pm 236.25^{\mathrm{ABC}}$ & $1709.00 \pm 560.75$ & $667.50 \pm 104.25$ & $656.25 \pm 95.75$ \\
\hline & 15 & $766.25 \pm 82.25^{\mathrm{A}}$ & $1022.62 \pm 257.12$ & $1123.12 \pm 336.12$ & $927.00 \pm 357.75$ \\
\hline & 30 & $1210.00 \pm 229.50^{\mathrm{AB}}$ & $1156.75 \pm 271.00$ & $1192.12 \pm 180.12$ & $521.75 \pm 111.50$ \\
\hline & 60 & $1994.87 \pm 450.87^{\mathrm{BC}}$ & $1359.37 \pm 238.62$ & $1468.12 \pm 282.87$ & $246.37 \pm 198.37$ \\
\hline & 90 & $2127.25 \pm 67.00^{\mathrm{Cy}}$ & $1065.75 \pm 210.25^{x}$ & $993.37 \pm 337.12^{x}$ & $765.87 \pm 203.62^{x}$ \\
\hline & 120 & $1019.25 \pm 72.50^{\mathrm{A}}$ & $885.50 \pm 96.25$ & $1587.37 \pm 345.87$ & $871.50 \pm 141.50$ \\
\hline
\end{tabular}

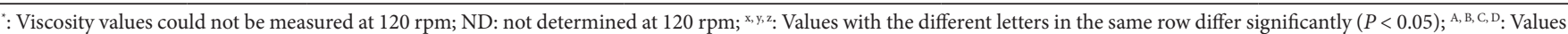
with the different letters in the same column differ significantly $(P<0.05)$; C: Sample produced from freezing the fermented mixture no adding fruit puree, $\mathrm{F}$ : Sample produced from addition of frozen raspberries to the fermented mixture, A: Sample produced from addition of commercial raspberry puree to the fermented mixture, B: Sample produced from addition of commercial blackberry puree to the fermented mixture. 
Table 4. Sensory properties of synbiotic ice creams produced from goat's milk

\begin{tabular}{|c|c|c|c|c|c|}
\hline & \multicolumn{5}{|c|}{ Synbiotic Ice Cream Samples } \\
\hline & Days & $\mathrm{C}$ & $\mathrm{F}$ & A & B \\
\hline \multirow[t]{6}{*}{ Color and appearance } & 1 & $4.12 \pm 0.12^{\mathrm{A}}$ & $4.25 \pm 0.25$ & $4.12 \pm 0.12^{\mathrm{A}}$ & $4.37 \pm 0.12$ \\
\hline & 15 & $5.00 \pm 0.00^{\mathrm{C}}$ & $4.31 \pm 0.19$ & $4.81 \pm 0.06^{\mathrm{BC}}$ & $4.62 \pm 0.12$ \\
\hline & 30 & $5.00 \pm 0.00^{\mathrm{Cy}}$ & $4.62 \pm 0.12^{\mathrm{x}}$ & $5.00 \pm 0.00^{\mathrm{Cy}}$ & $4.75 \pm 0.00^{x y}$ \\
\hline & 60 & $5.00 \pm 0.00^{\mathrm{C}}$ & $4.75 \pm 0.00$ & $5.00 \pm 0.00^{\mathrm{C}}$ & $5.00 \pm 0.00$ \\
\hline & 90 & $4.75 \pm 0.00^{\mathrm{B}}$ & $5.00 \pm 0.00$ & $4.75 \pm 0.00^{\mathrm{B}}$ & $5.00 \pm 0.00$ \\
\hline & 120 & $5.00 \pm 0.00^{\mathrm{C}}$ & $4.37 \pm 0.12$ & $4.75 \pm 0.00^{\mathrm{B}}$ & $4.12 \pm 0.37$ \\
\hline \multirow[t]{6}{*}{ Structure and consistency } & 1 & $4.00 \pm 0.25$ & $3.87 \pm 0.12^{\mathrm{A}}$ & $4.12 \pm 0.12^{\mathrm{A}}$ & $4.12 \pm 0.12^{\mathrm{A}}$ \\
\hline & 15 & $4.75 \pm 0.25$ & $4.31 \pm 0.31^{\mathrm{AB}}$ & $4.81 \pm 0.06^{\mathrm{B}}$ & $4.18 \pm 0.06^{\mathrm{A}}$ \\
\hline & 30 & $4.37 \pm 0.37$ & $4.75 \pm 0.00^{\mathrm{B}}$ & $4.37 \pm 0.12^{\mathrm{A}}$ & $4.87 \pm 0.12^{\mathrm{B}}$ \\
\hline & 60 & $4.81 \pm 0.06$ & $4.68 \pm 0.06^{\mathrm{B}}$ & $4.93 \pm 0.06^{\mathrm{B}}$ & $4.81 \pm 0.06^{\mathrm{B}}$ \\
\hline & 90 & $4.62 \pm 0.12$ & $4.62 \pm 0.12^{\mathrm{B}}$ & $4.43 \pm 0.06^{\mathrm{A}}$ & $4.81 \pm 0.19^{\mathrm{B}}$ \\
\hline & 120 & $4.81 \pm 0.19$ & $4.74 \pm 0.12^{\mathrm{B}}$ & $4.93 \pm 0.06^{\mathrm{B}}$ & $4.62 \pm 0.00^{\mathrm{B}}$ \\
\hline \multirow[t]{6}{*}{ Odor } & 1 & $3.75 \pm 0.25^{\mathrm{A}}$ & $4.12 \pm 0.37$ & $4.31 \pm 0.06^{\mathrm{A}}$ & $4.12 \pm 0.12$ \\
\hline & 15 & $4.37 \pm 0.12^{\mathrm{BC}}$ & $4.37 \pm 0.12$ & $4.50 \pm 0.00^{\mathrm{AB}}$ & $4.56 \pm 0.19$ \\
\hline & 30 & $4.12 \pm 0.12^{\mathrm{AB}}$ & $4.25 \pm 0.00$ & $4.50 \pm 0.00^{\mathrm{AB}}$ & $4.12 \pm 0.12$ \\
\hline & 60 & $4.87 \pm 0.12^{\mathrm{C}}$ & $4.87 \pm 0.12$ & $4.75 \pm 0.00^{\mathrm{B}}$ & $4.75 \pm 0.00$ \\
\hline & 90 & $4.50 \pm 0.00^{\mathrm{BCxy}}$ & $4.75 \pm 0.00^{y}$ & $4.37 \pm 0.12^{\mathrm{Ax}}$ & $4.75 \pm 0.00^{y}$ \\
\hline & 120 & $4.43 \pm 0.06^{\mathrm{BC}}$ & $4.68 \pm 0.06$ & $4.74 \pm 0.12^{\mathrm{B}}$ & $4.62 \pm 0.25$ \\
\hline \multirow[t]{6}{*}{ Taste } & 1 & $3.81 \pm 0.06^{\mathrm{BC}}$ & $4.12 \pm 0.00^{\mathrm{BC}}$ & $4.31 \pm 0.19$ & $4.24 \pm 0.12$ \\
\hline & 15 & $3.62 \pm 0.12^{\mathrm{Bx}}$ & $3.93 \pm 0.18^{\mathrm{ABxy}}$ & $4.43 \pm 0.18^{\mathrm{y}}$ & $4.43 \pm 0.06^{y}$ \\
\hline & 30 & $3.25 \pm 0.00^{\mathrm{Ax}}$ & $3.75 \pm 0.00^{\operatorname{Axy}}$ & $4.37 \pm 0.12^{\mathrm{z}}$ & $4.25 \pm 0.25^{y z}$ \\
\hline & 60 & $3.75 \pm 0.00^{\mathrm{BCx}}$ & $4.81 \pm 0.06^{\mathrm{Ez}}$ & $4.75 \pm 0.00^{z}$ & $4.50 \pm 0.00^{y}$ \\
\hline & 90 & $4.00 \pm 0.00^{\mathrm{Cx}}$ & $4.43 \pm 0.06^{\mathrm{CDy}}$ & $4.62 \pm 0.12^{\mathrm{yz}}$ & $4.87 \pm 0.12^{z}$ \\
\hline & 120 & $4.43 \pm 0.18^{\mathrm{D}}$ & $4.62 \pm 0.12^{\mathrm{DE}}$ & $4.87 \pm 0.00$ & $4.62 \pm 0.12$ \\
\hline
\end{tabular}

x,y, Values with the different letters in the same row differ significantly $(P<0.05)$; A,B,C,D,E: Values with the different letters in the same column differ significantly $(P<0.05)$; C: Sample produced from freezing the fermented mixture no adding fruit puree, F: Sample produced from addition of frozen raspberries to the fermented mixture, A: Sample produced from addition of commercial raspberry puree to the fermented mixture, B: Sample produced from addition of commercial blackberry puree to the fermented mixture.

sweetness. These properties were associated with high sensory scores in some studies (Di Criscio et al., 2010). Sensory properties of a product are the most important features that determine the appreciation of consumers. In this manner, the sensory evaluation of color and appearance, structure and consistency, smell and taste properties of ice cream samples by the panelists were given in Table 4. Data showed that the addition of berry like fruit purees and probiotics in ice cream had effect on the sensory properties of ice cream. The overall acceptability of samples in storage period were in the range of 3.81-4.87. Texture and taste evaluations yielded good results and no off-flavor was reported. These results were consistent with those reported by $\mathrm{Di}$ Criscio et al. (2010) who observed a synbiotic effect of prebiotics that helps in the survival of probiotic bacteria. Include the need of performing additional sensory studies as projective methods (Pinto et al., 2018), innovative methods based in consumer perception (Torres et al., 2017) and sensory properties (Mituniewicz-Małek et al., 2019)

\section{Conclusions}

As a result, it was determined that enrichment with fruit puree had a significant effect on Lactobacillus paracasei subsp. paracasei and Bifidobacterium spp. viability and color, appearance, flavor, taste and overall sensory scores of the ice cream samples. It was determined that the samples maintained their probiotic properties during storage and generally received good sensory scores. The effects of reducing the fat ratio and using sweeteners, in addition to natural sugars, on glycemic index can be investigated in the future studies.

\section{Acknowledgements}

The authors thank to Scientific Research Fund Council of Ege University (2012-ZRF-004) for the financial support.

\section{References}

Akalin, A. S., Karagozlu, C., \& Unal, G. (2008). Rheological properties of reduced-fat and low-fat ice cream containing whey protein isolate and inulin. European Journal of Food Research and Technology, 227(3), 889-895. http://dx.doi.org/10.1007/s00217-007-0800-z.

Akin, M. S. (2005). Effects of inulin and different sugar levels on viability of probiotic bacteria and the physical and sensory characteristics of probiotic fermented ice cream. Milchwissenschaft. Milk Science International, 60(3), 297-300.

Ayar, A., Siçramaz, H., Öztürk, S., \& Öztürk Yilmaz, S. (2018). Probiotics properties of ice creams produced with dietary fibres from by-products of the industry. International Journal of Dairy Technology, 71(1), 174-182. http://dx.doi.org/10.1111/1471-0307.12387.

Balthazar, C. F., Silva, H. L. A., Esmerino, E. A., Rocha, R. S., Moraes, J., Carmo, M. A. V., Azevedo, L., Camps, I., K.D Abud, Y., Sant'Anna, 
C., Franco, R. M., Freitas, M. Q., Silva, M. C., Raices, R. S. L., Escher, G. B., Granato, D., Senaka Ranadheera, C., Nazarro, F., \& Cruz, A. G. (2018). The addition of inulin and Lactobacillus casei 01 in sheep milk ice cream. Food Chemistry, 246, 464-472. http://dx.doi. org/10.1016/j.foodchem.2017.12.002. PMid:29291874.

Bodyfelt, F. W., Tobias, J., \& Trout, G. M. (1988). The sensory evaluation of dairy products (598 p.). Westport: AVI Publ.

Champagne, C. P., Gomes da Cruz, A., \& Daga, M. (2018). Strategies to improve the functionality of probiotics in supplements and foods. Current Opinion in Food Science, 22, 160-166. http://dx.doi. org/10.1016/j.cofs.2018.04.008.

Cottrell, J. I. L., Pass, G., \& Phillips, G. O. (1979). Assesment of polysaccharides as ice cream stabilizers. Journal of Food Science and Agriculture, 30(11), 1085-1089. http://dx.doi.org/10.1002/ jsfa.2740301111.

Dave, R. I., \& Shah, N. P. (1996). Evaluation of media for selective enumeration of Streptococcus thermophilus, Lactobacillus delbrueckii ssp. bulgaricus, Lactobacillus acidophilus, and Bifidobacteria. Journal of Dairy Science, 79(9), 1529-1536. http://dx.doi.org/10.3168/jds. S0022-0302(96)76513-X. PMid:8899517.

Di Criscio, T., Fratianni, A., Mignogna, R., Cinquanta, L., Coppola, R., Sorrentino, E., \& Panfili, G. (2010). Production of functional probiotic, prebiotic, and synbiotic ice creams. Journal of Dairy Science, 93(10), 4555-4564. http://dx.doi.org/10.3168/jds.20103355. PMid:20854989.

Donkor, O. N., Henriksson, A., Vasiljevic, T., \& Shah, N. P. (2006). Effect of acidification on the activity of probiotics in yoghurt during cold storage. International Dairy Journal, 16(10), 1181-1189. http:// dx.doi.org/10.1016/j.idairyj.2005.10.008

El-Nagar, G., Clowes, G., Tudorica, C. M., Kuri, V., \& Brennan, C. S. (2002). Rheological quality and stability of yog-ice cream with added inulin. International Journal of Dairy Technology, 55(2), 89-93. http:// dx.doi.org/10.1046/j.1471-0307.2002.00042.x.

Guimarães, J. T., Balthazar, C. F., Silva, R., Rocha, R. S., Graça, J. S., Esmerino, E. A., Silva, M. C., Sant'Ana, A. S., Duarte, M. C. K. H., Freitas, M. Q., \& Cruz, A. G. (2020). Impact of probiotics and prebiotics on food texture. Current Opinion in Food Science, 33, 38-44. http://dx.doi.org/10.1016/j.cofs.2019.12.002.

Guven, M., \& Karaca, O. B. (2002). The effects of the varying sugar content and fruit concentration on the physical properties of vanilla and fruit ice-cream-type frozen yogurts. International Journal of Dairy Technology, 55(1), 27-31. http://dx.doi.org/10.1046/j.14710307.2002.00034.x.

Heller, K. J. (2001). Probiotic bacteria in fermented foods: product characteristics and starter organisms. The American Journal of Clinical Nutrition, 73(2, Suppl.), 374S-379S. http://dx.doi.org/10.1093/ ajcn/73.2.374s. PMid:11157344.

Hill, C., Guarner, F., Reid, G., Gibson, G. R., Merenstein, D. J., Pot, B., Morelli, L., Canani, R. B., Flint, H. J., Salminen, S., Calder, P. C., \& Sanders, M. E. (2014). Expert consensus document: The international scientific association for probiotics and prebiotics consensus statement on the scope and appropriate use of the term probiotic. Nature Reviews. Gastroenterology \& Hepatology, 11(8), 506-514. http://dx.doi.org/10.1038/nrgastro.2014.66. PMid:24912386.

Homayouni, A., Azizi, A., Ehsani, M. R., Yarmand, M. S., \& Razavi, S. H. (2008). Effect of microencapsulation and resistant starch on the probiotic survival and sensory properties of synbiotic ice cream. Food Chemistry, 111(1), 50-55. http://dx.doi.org/10.1016/j. foodchem.2008.03.036.

Homayouni, A., Azizi, A., Javadi, M., Mahdipour, S., \& Ejtahed, H. (2012). Factors influencing probiotic survival in ice cream: a Review.
International Journal of Dairy Science, 7(1), 1-10. http://dx.doi. org/10.3923/ijds.2012.1.10.

Kalicka, D., Znamirowska, A., Pawlos, M., Buniowska, M., \& Szajnar, K. (2019). Physical and sensory characteristics and probiotic survival in ice cream sweetened with various polyols. International Journal of Dairy Technology, 72(3), 456-465. http://dx.doi.org/10.1111/14710307.12605.

Kechagia, M., Basoulis, D., Konstantopoulou, S., Dimitriadi, D., Gyftopoulou, K., Skarmoutsou, N., \& Fakiri, E. M. (2013). Health benefit of probiotics: a review. ISRN Nutrition, 2013, 481651. http:// dx.doi.org/10.5402/2013/481651. PMid:24959545.

Kesenkas, H., Akbulut, N., Yerlikaya, O., Akpinar, A., \& Acu, M. (2013). A research on usage possibilities of soy milk for kefir ice-cream production. Ege Journal of Agricultural Research, 50(1), 1-12.

Krumbeck, J. A., Maldonado-Gomez, M. X., Ramer-Tait, A. E., \& Hutkins, R. W. (2016). Prebiotics and synbiotics: dietary strategies for improving gut health. Current Opinion in Gastroenterology, 32(2), 110-119. http://dx.doi.org/10.1097/MOG.0000000000000249. PMid:26825589.

Lad, S.S., Aparnathi, K.D., Mehta, B., \& Velpula, S. (2017). Goat milk in human nutrition and health - a review. International Journal of Current Microbiology and Applied Science, 6(5), 1781-1792. https:// doi.org/10.20546/ijcmas.2017.605.194.

Markowiak, P., \& Śliżewska, K. (2017). Effects of probiotics, prebiotics, and synbiotics on human health. Nutrients, 9(9), 1021. http://dx.doi. org/10.3390/nu9091021. PMid:28914794.

Marshall, R. T., \& Arbuckle, W. S. (1996). Ice cream (5th ed.). New York: Chapman and Hall. http://dx.doi.org/10.1007/978-1-4613-0477-7.

Mituniewicz-Małek, A., Zielińska, D., \& Ziarno, M. (2019). Probiotic monocultures in fermented goat milk beverages - sensory quality of final product. International Journal of Dairy Technology, 72(2), 240-247. http://dx.doi.org/10.1111/1471-0307.12576.

Muse, M. R., \& Hartel, R. W. (2004). Ice cream structural elements that affect melting rate and hardness. Journal of Dairy Science, 87(1), 1-10. http://dx.doi.org/10.3168/jds.S0022-0302(04)73135-5. PMid:14765804.

O’Bryan, C. A., Pak, D., Crandall, P. G., Lee, S. O., \& Ricke, S. C. (2013). The Role of prebiotics and probiotics in human health. Journal of Probiotics and Health, 1(2), 1000108. http://dx.doi.org/10.4172/23298901.1000108.

Pandey, K. R., Naik, S. R., \& Vakil, B. V. (2015). Probiotics, prebiotics and synbiotics - a review. Journal of Food Science and Technology, 52(12), 7577-7587. http://dx.doi.org/10.1007/s13197-015-1921-1. PMid:26604335.

Paz, N. F., Oliveira, E. G., Kairuz, M. S. N., \& Ramón, A. N. (2014). Characterization of goat milk and potentially synbiotic non-fat yogurt. Food Science and Technology (Campinas), 34(3), 629-635. http://dx.doi.org/10.1590/1678-457x.6409.

Pinto, L. P. F., Silva, H. L. A., Kuriya, S. P., Maçaira, P. M., Cyrino Oliveira, F. L., Cruz, A. G., Esmerino, E. A., \& Freitas, M. Q. (2018). Understanding perceptions and beliefs about different types of fermented milks through the application of projective techniques: a case study using Haire's shopping list and free word association. Journal of Sensory Studies, 33(3), e12326. http://dx.doi.org/10.1111/ joss. 12326.

Ranadheera, C. S., Evans, C. A., Adams, M. C., \& Baines, S. K. (2012). Probiotic viability and physico-chemical and sensory properties of plain and stirred fruit yogurts made from goat's milk. Food Chemistry, 135(3), 1411-1418. http://dx.doi.org/10.1016/j.foodchem.2012.06.025. PMid:22953874. 
Ranadheera, C. S., Evans, C. A., Baines, S. K., Balthazar, C. F., Cruz, A. G., Esmerino, E. A., Freitas, M. Q., Pimentel, T. C., Wittwer, A. E., Naumovski, N., Graça, J. S., Sant'Ana, A. S., Ajlouni, S., \& Vasiljevic, T. (2019). Probiotics in goat milk products: delivery capacity and ability to improve sensory attributes. Comprehensive Reviews in Food Science and Food Safety, 18(4), 867-882. http:// dx.doi.org/10.1111/1541-4337.12447.

Ranadheera, C. S., Naumovski, N., \& Ajlouni, S. (2018). Non-bovine milk products as emerging probiotic carriers: Recent developments and innovations. Current Opinion in Food Science, 22, 109-114. http://dx.doi.org/10.1016/j.cofs.2018.02.010.

Sarfraz, F., Farooq, U., Shafi, A., Hayat, Z., Akram, K., \& Rehman, H. U. (2019). Hypolipidaemic effects of synbiotic yoghurt in rabbits. International Journal of Dairy Technology, 72(4), 1-6. http://dx.doi. org/10.1111/1471-0307.12618.

Schmidt, K., Lundy, A., Reynolds, J., \& Yee, L. N. (1993). Carbonhydrate or protein based fat mimicker effect on ice milk properties. Journal of Food Science, 58(4), 761-779. http://dx.doi.org/10.1111/j.1365-2621.1993. tb09353.x.

Shafi, A., Naeem Raja, H., Farooq, U., Akram, K., Hayat, Z., Naz, A., \& Nadeem, H. R. (2019). Antimicrobial and antidiabetic potential of synbiotic fermented milk: a functional dairy product. International Journal of Dairy Technology, 72(1), 15-22. http://dx.doi. org/10.1111/1471-0307.12555.

Shiby, V. K., \& Mishra, H. N. (2013). Fermented milks and milks products as functional foods-a review. Critical Reviews in Food Science and Nutrition, 53(5), 482-496. http://dx.doi.org/10.1080/10408398.201 0.547398. PMid:23391015.

Tharmaraj, N., \& Shah, N. P. (2003). Selective Enumeration of Lactobacillus delbrueckii ssp. bulgaricus, Streptococcus thermophilus, Lactobacillus acidophilus, Bifidobacteria, Lactobacillus casei, Lactobacillus rhamnosus and Propionibacteria. Journal of Dairy Science, 86(7), 2288-2296. http://dx.doi.org/10.3168/jds.S0022-0302(03)73821-1. PMid:12906045.

Tokuc, K., Demirci, M., Bilgin, B., \& Arici, M. (2008, May 21-23). Baby origin Lactobacillus spp. produce probiotic ice cream using and identify some other properties with probiotic bacteria viability during storage. In Proceedings of the 10th Food Congress. Erzurum, Turkey: Food Technology Association.

Torres, F. R., Esmerino, E. A., Carr, B. T., Ferrão, L. L., Granato, D., Pimentel, T. C., Bolini, H. M. A., Freitas, M. Q., \& Cruz, A. G. (2017). Rapid consumer-based sensory characterization of requeijão cremoso, a spreadable processed cheese: performance of new statistical approaches to evaluate check-all-that-apply data. Journal of Dairy Science, 100(8), 6100-6110. http://dx.doi.org/10.3168/ jds.2016-12516. PMid:28571992.

Uysal, H., Kinik, O., \& Kavas, G. (2004). Sensory testing techniques applied in milk and milk products (No. 560, 101 p.). Izmir: Faculty of Agriculture Publications, Ege University.

Vasconcelos, F. M., Silva, H. L. A., Poso, S. M., Barroso, M. V., Lanzetti, M., Rocha, R. S., Graça, J. S., Esmerino, E. A., Freitas, M. Q., Silva, M. C., Raices, R. S. L., Granato, D., Pimentel, T. C., Sant'Ana, A. S., Cruz, A. G., \& Valença, S. S. (2019). Probiotic prato cheese attenuates cigarette smoke-induced injuries in mice. Food Research International, 123, 697-703. http://dx.doi.org/10.1016/j.foodres.2019.06.001. PMid:31285019.

Zenebe, T., Ahmed, N., Kabeta, T., \& Kebede, G. (2014). Review on medicinal and nutritional values of goat milk. Academic Journal of Nutrition, 3(3), 30-39. http://dx.doi.org/10.5829/idosi. ajn.2014.3.3.93210. 